\title{
cAMP promotes the differentiation of neural progenitor cells in vitro via modulation of voltage-gated calcium channels
}

\author{
Guilherme Lepski ${ }^{1,2}$, Cinthia E. Jannes ${ }^{1,3}$, Guido Nikkhah ${ }^{1,4}$ and Josef Bischofberger ${ }^{5,6}$ \\ 1 Department of Functional and Stereotactic Neurosurgery, University Albert-Ludwig, Freiburg, Germany \\ ${ }^{2}$ Department of Neurosurgery, Eberhard Karls University, Tübingen, Germany \\ ${ }^{3}$ Institute of Cardiology, Universidade de São Paulo, São Paulo, Brazil \\ ${ }^{4}$ Department of Stereotactic Neurosurgery, University Clinic Erlangen, Erlangen, Germany \\ ${ }^{5}$ Department of Biomedicine, Institute of Physiology, University of Basel, Basel, Switzerland \\ ${ }^{6}$ Department of Physiology, University Albert-Ludwig, Freiburg, Germany
}

Edited by:

Rena Li, Roskamp Institute, USA

Reviewed by:

Enrico Cherubini, International School for Advanced Studies, Italy

Shaoyu Ge, SUNY Stony Brook, USA

\section{*Correspondence:}

Guilherme Lepski, Department of

Neurosurgery, Eberhard Karls

University, Hoppe-Seyler-Strasse 3,

72076 Tübingen, Germany

e-mail: lepski@gmail.com
The molecular mechanisms underlying the differentiation of neural progenitor cells (NPCs) remain poorly understood. In this study we investigated the role of $\mathrm{Ca}^{2+}$ and $\mathrm{CAMP}$ (cyclic adenosine monophosphate) in the differentiation of NPCs extracted from the subventricular zone of E14.5 rat embryos. Patch clamp recordings revealed that increasing CAMP-signaling with Forskolin or IBMX (3-isobutyl-1-methylxantine) significantly facilitated neuronal functional maturation. A continuous application of IBMX to the differentiation medium substantially increased the functional expression of voltage-gated $\mathrm{Na}^{+}$and $\mathrm{K}^{+}$ channels, as well as neuronal firing frequency. Furthermore, we observed an increase in the frequency of spontaneous synaptic currents and in the amplitude of evoked glutamatergic and GABAergic synaptic currents. The most prominent acute effect of applying IBMX was an increase in L-type $\mathrm{Ca}^{2+}$ currents. Conversely, blocking L-type channels strongly inhibited dendritic outgrowth and synapse formation even in the presence of IBMX, indicating that voltage-gated $\mathrm{Ca}^{2+}$ influx plays a major role in neuronal differentiation. Finally, we found that nifedipine completely blocks IBMX-induced CREB phosphorylation (cAMP-response-element-binding protein), indicating that the activity of this important transcription factor equally depends on both enhanced CAMP and voltage-gated $\mathrm{Ca}^{2+}$-signaling. Taken together, these data indicate that the up-regulation of voltage-gated L-type $\mathrm{Ca}^{2+}$-channels and early electrical excitability are critical steps in the cAMP-dependent differentiation of SVZ-derived NPCs into functional neurons. To our knowledge, this is the first demonstration of the acute effects of cAMP on voltage-gated $\mathrm{Ca}^{+2}$ channels in NPC-derived developing neurons.

Keywords: neural stem cells, cell differentiation, patch-clamp techniques, calcium signaling, cyclic AMP

\section{INTRODUCTION}

Previous studies have reported the generation (in vitro) of functional neurons from neural stem cells/progenitor cells derived from fetal (Auerbach et al., 2000), neonatal (Scheffler et al., 2005), and adult (Song et al., 2002) brain tissue. It is wellknown that neural stem cell proliferation and differentiation depend on several growth factors, hormones, and neurotransmitters. Nevertheless, the precise molecular mechanisms underlying neurodifferentiation remain poorly understood.

The activation of many G-protein-coupled receptors stimulates cAMP production as well as CREB [CAMP response element (CRE) binding protein] phosphorylation, two processes believed to be important for NPC proliferation and differentiation (Dworkin and Mantamadiotis, 2010). For adult neural stem cells, (Fujioka et al., 2004) showed that prolonged cAMP elevation induced by Forskolin increases the length and number of dendritic branches as well as the number of MAP2ab (microtubule-associated-protein $2 \mathrm{ab}$ ) positive cells during the first 2 weeks of differentiation. Furthermore, cAMP's effects on morphological maturation are believed to depend on CREB activation (e.g., via phosphorylation by PKA at Ser-133; Jagasia et al., 2009). Once activated, CREB can bind to the promoter region of genes containing CRE. Whereas phosphorylated CREB (pCREB) is basically absent in stem cells, it is transiently up-regulated in NPCs and young neurons during the first few weeks of differentiation (Merz et al., 2011). The amount of available pCREB during this time period correlates with the total dendritic length and the morphological maturity of the young neurons (Giachino et al., 2005), while the expression of dominant negative pCREB has been shown to strongly interfere with their survival and differentiation (Herold et al., 2011).

In addition to PKA, other $\mathrm{Ca}^{2+}$-dependent protein kinases are known to be potent activators of CREB-mediated gene transcription, for example, mitogen-activated protein kinase (MAPK) 
and $\mathrm{Ca}^{2+}$ calmodulin-dependent protein kinase IV (CaMKIV), found predominantly in the nucleus (Deisseroth et al., 2003). (Redmond et al., 2002) showed that CREB phosphorylation is mediated by CaMKIV and blocked by L-type $\mathrm{Ca}^{2+}$ channel antagonists. Consistent with these observations, NPC-derived neurons express L-type $\mathrm{Ca}^{2+}$ channels a few days after mitosis and show spontaneous $\mathrm{Ca}^{2+}$ oscillations, which have been shown to support neuronal differentiation (D'Aascenzo et al., 2006). Much less is known about the impact of $\mathrm{Ca}^{2+}$ channel modulation on the functional properties of NPCs. Most importantly, almost nothing is known about the functional interaction between cAMP- and $\mathrm{Ca}^{2+}$-dependent pathways during the differentiation of NPCs into functional neurons.

In the current study we investigated the crosstalk between cAMP and $\mathrm{Ca}^{2+}$-signaling during the differentiation of SVZderived NPCs. We independently tested the effects of BDNF, NT3, IBMX, and Forskolin on neuronal differentiation. Our results revealed that applying the phosphodiesterase inhibitor IBMX elevates cAMP levels, which in turn strongly accelerates the generation of action potentials and the development of functional inhibitory and excitatory synapses. Enhanced cAMP levels increased $\mathrm{Ca}^{2+}$ influx via the voltagegated L-type $\mathrm{Ca}^{2+}$ channels, which in turn facilitated CREB phosphorylation. This proved to be a critical step toward neuronal differentiation and the formation of functional synapses.

\section{MATERIALS AND METHODS CELL CULTURE}

All experiments were approved by the Research Ethics Committee of the Albert-Ludwig University, in Freiburg. Neural stem cells were originally isolated from E14.5 Sprague-Dawley rat fetuses, as previously described (Lepski et al., 2011a). Pregnant females were anesthetized with an intraperitoneal injection of ketamine (Essex Pharma, Munique), the fetuses were extracted, the telencephalic vesicle was then dissected and digested with trypsin $0.05 \%$ (Worthington, Lakewood, New Jersey, USA) and DNAse $0.05 \%$ (Sigma, St. Louis, Missouri, USA). After mechanical trituration, the resulting suspension was cultured in medium comprising DMEM, F12, 2 mM L-Glutamine, 2\% B27 serum supplement, $1 \%$ PSA (all purchased from Gibco), $20 \mathrm{ng} / \mathrm{mL}$ basic fibroblast growth factor (bFGF, Sigma), $20 \mathrm{ng} / \mathrm{mL}$ epidermal growth factor (EGF, PeproTech, London, UK), $5 \mu \mathrm{g} / \mathrm{mL}$ heparin (Sigma), and incubated at $37^{\circ} \mathrm{C}, 5 \% \mathrm{CO}_{2}, 21 \% \mathrm{O}_{2}$, and $95 \%$ humidity. Medium was changed every other day, and passages performed once a week by light mechanical dissociation of the formed spheres. Cultures of neural stem cells between passages 3 and 5 were used in this study. For neuronal differentiation, a previously tested protocol for human fetal neuronal progenitors was employed (Lepski et al., 2010). NPCs isolated according to this protocol were able to generate mature neurons, oligodendrocytes and astrocytes in differentiation medium (Figure A1). After a minimum of 3 passages, cells were plated at high densities on poly-L-ornithine (Sigma) coated coverslips placed into 24-well plates in a medium comprising MEM (Sigma), 1\% N2 serum supplement, $1 \%$ sodium pyruvate, $2 \mathrm{mM} \mathrm{L-glutamine,} 4 \mathrm{mM}$ glucose, $0.1 \%$ bovine serum albumin, $1 \%$ PSA, supplemented with
BDNF $25 \mathrm{ng} / \mathrm{mL}$ and $0.5 \mathrm{mM} 3$-isobutyl-1-methylxantine (IBMX, Sigma). In some experiments, $10 \mathrm{ng} / \mathrm{mL}$ Neurotrophin-3 (NT3, Sigma) and $10 \mu \mathrm{M}$ Forskolin (Sigma) were added separately to the differentiation medium, as described in the results. In order to block neuronal differentiation, $50 \mu \mathrm{M} \mathrm{Ni}$ and $100 \mathrm{nM}$ TTX, $200 \mu$ M EGTA (Sigma), $50 \mu \mathrm{M}$ Cd (Merck, Darmstadt, Germany), $10 \mu \mathrm{M}$ nifedipine (Sigma) were added to the medium containing IBMX throughout the differentiation period. Medium was changed completely every other day. Cells were fixed and immunostained immediately after electrophysiological recording, at different time points during the first week or on the seventh day.

\section{ELECTROPHYSIOLOGY}

At different time points during the differentiation process (at $1,3,5$, and 7 days in vitro), the cultured coverslips were transferred to a recording chamber and continuously superfused with physiological extracellular saline at a flow rate of $5-10 \mathrm{~mL} / \mathrm{min}$ (chamber volume $\sim 2 \mathrm{~mL}$ ). Neuronal cells were visually identified based on the presence of short or long neuritic elongations. Cells with GAP junctions, which are present in astrocytes, were discarded if patched accidentally. Further details related to the electrophysiological methods have been published previously (Lepski et al., 2010). The saline contained (in $\mathrm{mM}$ ): $125 \mathrm{NaCl}, 25 \mathrm{NaHCO}_{3}$, $2.5 \mathrm{KCl}, 1.25 \mathrm{NaH}_{2} \mathrm{PO}_{4}, 25$ Glucose, $2 \mathrm{CaCl}_{2}$, and $1 \mathrm{MgCl}_{2}$ (equilibrated with $95 \% \mathrm{O}_{2}, 5 \% \mathrm{CO}_{2}$ ). An Axopatch $200 \mathrm{~A}$ amplifier (Axon Instruments, Foster City, CA) was used for voltage-clamp and current-clamp (I-clamp fast) recordings. Current and voltage signals were filtered at $5-10 \mathrm{kHz}$, with a 4-pole low pass Bessel filter and digitalized at 10 or $20 \mathrm{kHz}$ with a 1401 plus interface (CED, Cambridge Electronic Design, Cambridge, UK) connected to a personal computer. Only cells with seal resistance $\left(\mathrm{R}_{\text {seal }}\right)$ larger than three times the input resistance $\left(R_{\text {in }}\right)$ were used in this study.

For whole cell current clamp recordings, we used 4-9 M $\Omega$ patch pipettes filled with an internal solution containing (in $\mathrm{mM}$ ): $120 \mathrm{~K}$-gluconate, $20 \mathrm{KCl}, 10 \mathrm{EGTA}, 2 \mathrm{MgCl}_{2}, 2 \mathrm{NA}_{2} \mathrm{ATP}$, 10 HEPES ( $\mathrm{pH}$ adjusted to 7.3 with $\mathrm{KOH}$ ). Bridge balance was used to compensate the series resistance of 20-40 M $\Omega$. In addition, capacitance compensation was used to decrease the charging time of the pipette to less than 50 microseconds. The holding potential was set to $-80 \mathrm{mV}$ by applying a small hyperpolarizing holding current if necessary.

Currents were evoked by applying 15 voltage pulses from a holding potential of $-80 \mathrm{mV}$, starting at $-70 \mathrm{mV}$ with $10 \mathrm{mV}$ increments up to $+70 \mathrm{mV}$. Leak and capacitive currents were subtracted using a $\mathrm{P} /-4$ protocol, as described elsewhere (Lepski et al., 2010). All experiments were performed at $22^{\circ} \mathrm{C} . \mathrm{Na}^{+}$- and $\mathrm{K}^{+}$-peak currents were calculated from 5 and 100 data points, from the minimal and maximal curve values, respectively. Cell capacitance was calculated by monoexponential fitting from the averaged current trace, by applying 50 pulses of $-10 \mathrm{mV}$ and $100 \mathrm{~ms}$ from a holding potential of $-80 \mathrm{mV}$.

$\mathrm{Ca}^{2+}$-current measurements were taken by filling the pipette with an internal solution containing (in $\mathrm{mM}$ ): $137 \mathrm{CsCl}, 4$ $\mathrm{MgCl}_{2}, 10$ EGTA, 10 HEPES, $4 \mathrm{Na}_{2} \mathrm{ATP}, 10 \mathrm{Na}_{2}$-phosphocreatin, 
$0.3 \mathrm{NaGTP}$ ( $\mathrm{pH}$ adjusted to 7.3 with $\mathrm{CsOH}$ ). The bath solution used in these experiments contained (in $\mathrm{mM}$ ): $105 \mathrm{NaCl}$, $25 \mathrm{NaHCO}_{3}, 25$ glucose, $2.5 \mathrm{KCl}, 1.25 \mathrm{NaH}_{2} \mathrm{PO} 4,2 \mathrm{CaCl}_{2}, 1$ $\mathrm{MgCl}_{2}, 1 \mu \mathrm{M}$ tetrodotoxin, 20 tetraethylammonium chloride, and 4 4-aminopyridine to block voltage-gated $\mathrm{Na}^{+}$and $\mathrm{K}^{+}$ channels, respectively.

To measure $\mathrm{Ca}^{2+}$-currents, we used $\mathrm{Cd}^{2+}(50 \mu \mathrm{M})$ to nonspecifically block all $\mathrm{Ca}^{2+}$ channels, $\mathrm{Ni}^{2+}$ to block T-type $(50 \mu \mathrm{M})$, nifedipine $(10 \mu \mathrm{M})$ was used to block L-type highvoltage activated channels, $\omega$-conotoxin GVIA $(1 \mu \mathrm{M})$ to block N-type, SNX482 (100 nM) to block R-type, and $\omega$-agatoxin IVA $(250 \mathrm{nM})$ to block P/Q-type $\mathrm{Ca}^{2+}$ channels. All chemicals were purchased from Alomone Labs (Jerusalem, Israel).

Recordings of evoked synaptic currents were performed with a bipolar macroelectrode using voltage pulses with a duration of 200 microseconds and an amplitude of $1-10 \mathrm{~V}$ (5 stimuli at $10 \mathrm{~Hz}$ ). For pharmacological identification of the evoked GABAergic and glutamatergic synaptic currents, $10 \mu \mathrm{M}$ bicuculline methiodide and $10 \mu \mathrm{M}(\mathrm{CNQX})$ were added to the external saline to block $\mathrm{GABA}_{\mathrm{A}}$ and AMPA receptors, respectively.

During the recording session, cells were filled with biocytin (Molecular Probes, $1 \mathrm{mg} / \mathrm{mL}$ ). All patched cells were fixed and double-stained for biocytin and a neuronal marker, MAP2 or $\beta I I I-t u b u l i n$, for phenotypic confirmation.

For data analysis, traces and data points were fitted using a nonlinear least-squares algorithm. Sodium and calcium peak currents were determined based on 5 data points at the maximum inward current value. Similarly, the potassium peak current was calculated from 100 data points at the maximal outward current value. Current densities were calculated by dividing the peak current by the cell capacitance. The evoked synaptic currents were averaged and subtracted from the currents recorded during pharmacological blocking (bicuculline and CNQX) in order to reduce the stimulation artifact. To analyze the decay phase, synaptic currents were fitted with a bi-exponential function and the amplitude-weighted time constant $\tau_{\mathrm{w}}$ was calculated according to the following equation:

$$
\tau_{\mathrm{w}}=\left(A_{1} \tau_{1}+A_{2} \tau_{2}\right) /\left(A_{1}+A_{2}\right)
$$

where $A_{1}$ and $\tau_{1}$ represent amplitude and time constant from component 1 , and $A_{2}$ and $\tau_{2}$ for component 2 .

The steady state activation curves of voltage-gated channels were obtained from the respective peak currents, assuming ohmic behavior. The activation of $\mathrm{Na}^{+}$- and $\mathrm{K}^{+}$-currents ( $\mathrm{I}-\mathrm{V}$ relationship) was fitted with the following equation derived from the Boltzmann equation multiplied with a driving force, considering the reversal potential for $\mathrm{K}^{+}$and for $\mathrm{Na}^{+}$, calculated as $-95 \mathrm{mV}$ and $80 \mathrm{mV}$, respectively, according to the Nernst equation with the solutions used.

$$
I(V)=\left[(V-E) G_{\max }\right] /\left\{1+\exp \left[-\left(V-V_{1 / 2}\right) / k\right]\right\}
$$

where $V$ is the membrane potential, $E$ is the Nernst reversal potential, $G_{\max }$ is the maximal conductance, $V_{1 / 2}$ is the potential at which the value of the Boltzmann function is 0.5 , and $k$ is the slope factor.
The I-V relationships for $\mathrm{Ca}^{2+}$ currents were fitted with a modified Goldman-Hodgkin-Katz equation of the form:

$$
\begin{aligned}
I(V)_{\mathrm{Ca}}= & P V([D-\exp (-V / C)] /[1-\exp (V / C)]) \\
& *\left(1 /\left\{1+\exp \left[\left(V_{1 / 2}-V\right) / k\right]\right\}\right)
\end{aligned}
$$

with voltage $V$, amplitude factor $P$, steepness factor $C$, and parameter $D$ determining current rectification and reversal potential.

\section{IMMUNOCYTOCHEMISTRY AND CONFOCAL IMAGING}

Immunostaining of cell cultures was carried out as previously described (Lepski et al., 2010, 2011b). The following primary antibodies and dilutions were used (ms, mouse; rb, rabbit): anti-MAP2ab (1:200, ms, Chemicon), anti-MAP2 (1:600, rb, Chemicon), anti-synaptophysin (1:1000, ms, Chemicon), antiGFAP (1:600, rb, DAKO), anti-nestin (1:200, ms, Chemicon), anti-RIP (1:1000, ms, Chemicon), anti-pCREB (1:1000, mouse monoclonal, Chemicon). The secondary antibodies used were Alexa 488 goat anti-rabbit or anti-mouse (1:150, Molecular Probes), Alexa 594 goat anti-rabbit or anti-mouse (1:150, Molecular Probes); biocytin staining was revealed by fluoresceinavidin D (1:500, Vector Laboratories, Burlingame, CA). Nuclei were stained with 4,6-diamidino-2-phenylindole dihydrochloride (DAPI, 1:10,000, Sigma). Photographs were taken on a Leica TCS SP2 confocal system (405 nm diode, Ar/ArKr, HeNe 543/594 lasers), with $20 \mathrm{x} / 0.7$ (air) or $63 \mathrm{x} / 1.2$ (oil) objectives. One digital frame comprised an area of $0.562 \mathrm{~mm}^{2}$. For quantifications, ten consecutive images were systematically scanned from left to the right at the horizontal diameter of each coverslip for each culture condition corresponding to about $5 \%$ of the entire surface area of the coverslips $\left(113 \mathrm{~mm}^{2}\right)$. Cells positive for a specific marker were counted in highly magnified digital frames, scanned at $4 \mu \mathrm{m}$ to avoid overprint, in relation to the total amount of DAPI-stained nuclei, using ViewFinder 2.1 software (ERDAS, Atlanta). For quantification of fluorescence intensity, experiments were performed in parallel and the groups to be compared were stained in one session. Measurements of fluorescence levels were performed on the same day using a Leica TCS SP2 confocal system. The laser parameters were kept constant during all measurements.

In addition to the number of immunopositive cells, we quantified the relative immunofluorescence for MAP2ab and synaptophysin. To do so, we measured the background fluorescence intensity F0 from a cell-free region of interest (ROI) within each individual image. Subsequently, the relative mean fluorescence intensity $(\mathrm{F}-\mathrm{F} 0) / \mathrm{F} 0$ of the total image was calculated using the Leica SP2 software. Experiments were done in triplicate and counts were performed in a double-blind manner.

\section{CELL VIABILITY ASSAY}

To assess cell viability under different culture conditions, we used the Live/Dead Cell Viability Kit (Molecular Probes). The test is based on differential membrane permeability of the two kit components, Syto-10@ green fluorescent nucleic acid stain, which is highly permeable to all cells, and Dead Red $\odot$, an ethidium homodimer-2, which is a cell impermeant dye that labels only cells with compromised membranes. Initially, a working solution containing $2 \mathrm{uL}$ of each component diluted in $1 \mathrm{~mL}$ HBSS 
(HEPES-buffered saline solution) is prepared. The solution is comprised of $135 \mathrm{mM} \mathrm{NaCl}, 5 \mathrm{mM} \mathrm{KCl}, 1 \mathrm{mM} \mathrm{MgSO}_{4}, 1.8 \mathrm{mM}$ $\mathrm{CaCl}_{2}, 10 \mathrm{mM}$ HEPES, pH 7.4. Thereafter, $10^{6}$ cells in culture medium are transferred to Falcon tubes and centrifuged at $250 \mathrm{~g}$ for $10 \mathrm{~min}$. The medium is completely removed and cells are re-suspended in $200 \mathrm{uL}$ of the diluted dye. Cells are then incubated in darkness at room temperature for $15 \mathrm{~min}$. Next, cells are pelleted again by centrifugation, the supernatant is carefully removed, and cells are re-suspended in a minimum volume of $50 \mathrm{uL}$ fresh HBSS. This is followed by fixation for over $1 \mathrm{~h}$ in $4 \%$ fresh prepared glutaraldehyde. Finally, the fixative is removed and cells are re-suspended in HBSS prior to observation and quantification.

\section{STATISTICAL ANALYSIS}

Electrophysiological data were analyzed and fitted using Igor 5.03 (Wavemetrics). All data are expressed as mean \pm s.e.m. where error bars in the figures also represent s.e.m.; the statistical significance was assessed with a two-tailed Mann-Whitney U test at the significance level $(p)$ indicated $\left({ }^{*} p<0.05,{ }^{* *} p<0.01\right.$, and $* * * p<0.001)$.

\section{RESULTS}

\section{CAMP-INDUCED NEURONAL DIFFERENTIATION}

First, we tested neural differentiation under the effects of BDNF, NT3, IBMX, or Forskolin. In basal medium, the yield of MAP2ab-positive cells after 7 days increased from $6.4 \pm$ $1.2 \%$ to $10.3 \pm 1.3$ when BDNF was added to the medium $(n=10, p<0.05)$. Likewise, adding NT3 increased cell production to $10.9 \pm 1.3 \% \quad(n=10, p<0.01)$. A significantly greater increase in the number of MAP2ab positive cells was obtained when the intracellular cAMP concentration was elevated by adding the adenylatecyclase-activator Forskolin $(22.6 \pm$ $4.7 \% ; n=10, p<0.001)$ or the phosphodiesterase inhibitor 3-isobutyl-1-methylxanthine (IBMX) $(29.7 \pm 3.7 \%$; $n=10, p<$ $0.001)$. Interestingly, no summation effect was observed when Forskolin and IBMX were simultaneously added to the system $(24.2 \pm 4.3 \%, n=10, p<0.01)$, suggesting a saturation effect (Figure 1).

Immunocytochemical markers revealed the presence of morphologically mature neuronal cells at the end of the 1-week differentiation period, but the functional properties of these cells were not yet evident. In a previous study, our group demonstrated that functional maturation may be delayed in relation to morphological development (Lepski et al., 2011b); we therefore performed electrophysiological patch-clamp recordings on the seventh day of differentiation. In voltage clamp mode, larger $\mathrm{Na}^{+}$- and $\mathrm{K}^{+}$currents were recorded in IBMX (Figure 2). In basal medium, the $\mathrm{Na}^{+}$-peak conductance was $3.24 \pm 0.57, n s$, whereas the maximal $\mathrm{K}^{+}$conductance was $14.23 \pm 1.27$, ns. When BDNF was added to the differentiation medium, conductance levels increased to $9.68 \pm 1.38, n s(n=13, p<0.001)$ and 23.69 $\pm 5.18, n s(n=13$, $p=0.1713)$, respectively. Under IBMX, the peak $\mathrm{Na}^{+}$and $\mathrm{K}^{+}$conductance increased to $35.13 \pm 7.04$, ns $(n=13, p<0.001)$ and $33.43 \pm 7.41$, $n s(n=13, p<0.05)$, respectively. In current clamp mode, action potentials were evoked under IBMX in $63.2 \%$ of the cells (Figure 2 ). By contrast, only $21.7 \%$ of the cells

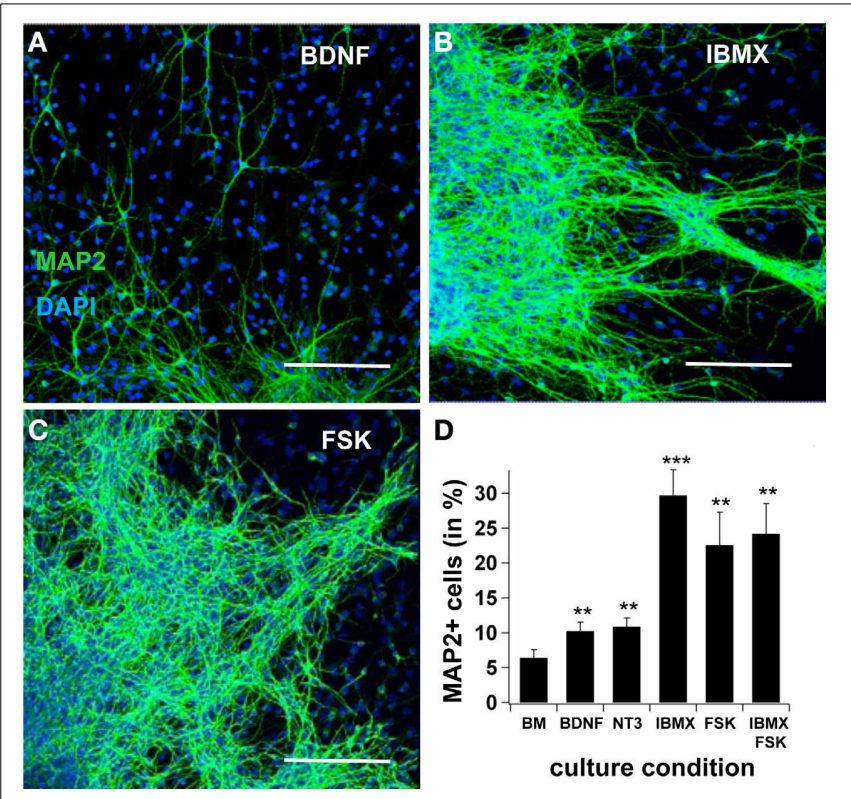

FIGURE 1 | cAMP induces neuronal differentiation. In (A), (B) and (C), confocal pictures showing MAP2ab-positivity in cultures maintained in BDNF, IBMX, and Forskolin after 7 days, with pictures taken at the border of the spheres. In (D), quantification of MAP2+-cells after 7 days in basal medium, BDNF alone, IBMX, Forskolin and IBMX and Forskolin. The highest yield of neuronal cells was observed in IBMX, and adding Forskolin did not increase the yield of differentiated cells. Green is AlexaFluor488. Scale bar $150 \mu \mathrm{m}$.

cultivated in BDNF and $13.5 \%$ of the cells grown in basal medium fired action potentials.

On the 7th day of differentiation in the IBMX-containing medium, a larger proportion of cells expressed the mature neuronal cell marker MAP2ab and the pre-synaptic vesicle marker synaptophysin (see Figure 3A). Spontaneous synaptic activity was recorded in normal saline and with increased $\mathrm{KCl}(12.5 \mathrm{mM}$; Figures 3B-E). Synaptic current responses were evoked using a bipolar stimulation electrode, and current-components were identified with specific pharmacological blockers. A GABAergic component sensitive to bicuculline was identified in all cells, and an AMPA-component sensitive to 6-cyano-7-nitroquinoxaline2,3 -dione (CNQX) was present in $67 \%$ of the cells. Bicuculline blocked $74.6 \pm 7.8 \%$ of the synaptic current, whereas CNQX blocked $25.4 \pm 7.8 \%$ of the total current (Figures 3F-I).

Taken together, results showed that the functional maturation of NPCs was substantially improved by cAMP signaling. Furthermore, many more cells were able to fire action potentials and form functional glutamatergic and GABAergic synaptic contacts when IBMX was applied.

\section{NEURONAL DIFFERENTIATION WAS IMPAIRED BY TETRODOTOXIN AND SPECIFIC $\mathrm{Ca}^{2+}$-CHANNEL BLOCKERS}

Next, we tested neuronal differentiation in the presence of three different channel blockers: tetrodotoxin (TTX; to block Navchannels), $\mathrm{Cd}^{2+}$ and $\mathrm{Ni}^{2+}$ (to block Cav-channels), and nifedipine (to specifically block L-type $\mathrm{Ca}^{2+}$ channels). In addition, we 


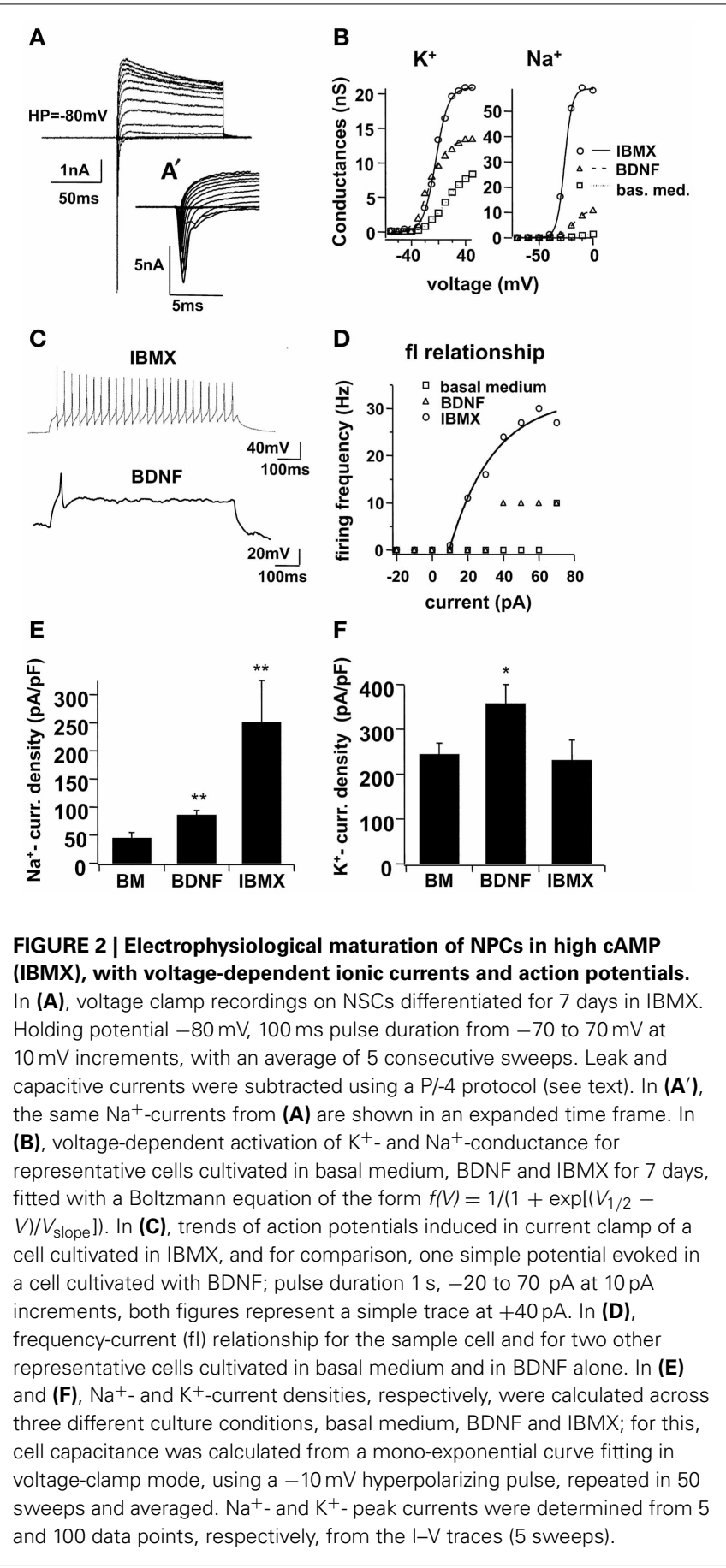

applied the $\mathrm{Ca}^{2+}$ buffer EGTA to study the impact of intracellular $\mathrm{Ca}^{2+}$ signals (Figure 4).

In the presence of IBMX/BDNF, the relative number of MAP2ab positive cells was significantly decreased from $27.1 \pm 1.0 \%$ to $19.6 \pm 1.6 \%$ when adding TTX $(p<0.001$, Figures $4 \mathrm{~A}, \mathrm{~B})$, indicating that electrical activity contributes to early NPC differentiation. An even larger effect was seen when we directly interfered with $\mathrm{Ca}^{2+}$ signaling, resulting in a proportion of MAP2 positive neurons of $13.2 \pm 1.2 \%$ in
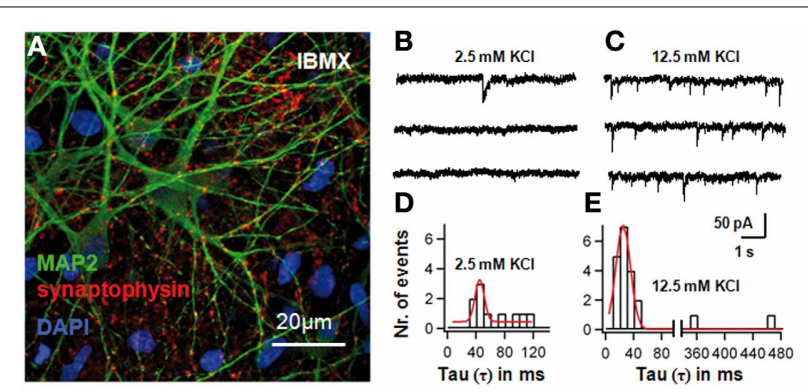

$\mathbf{F}$

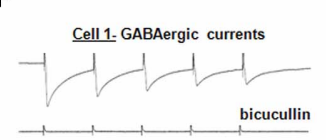

G

H
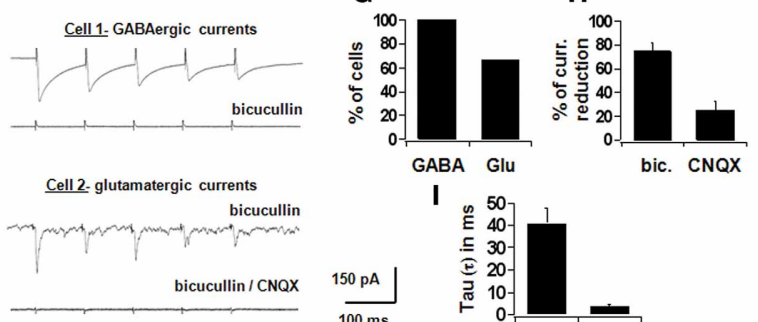

$150 \mathrm{pA}$

I 50

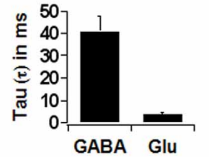

FIGURE 3 | Electrophysiological differentiation of NPCs in IBMX, with spontaneous and evoked synaptic currents. In (A), confocal picture showing MAP2 and synaptophysin positivity after 7 days in differentiation medium with IBMX. Red is AlexaFluor568 and green is AlexaFluor488. In (B) and (C), spontaneous synaptic recordings in voltage clamp in normal saline and with increased $\mathrm{KCl}(12.5 \mathrm{mM})$. In (D) and (E), histograms of the time constants of all synaptic events in normal saline and in increased $\mathrm{KCl}$, fitted with a Gaussian curve; best-fit parameters were $37 \pm 9 \mathrm{~ms}$ for low $\mathrm{KCl}$ and $20 \pm 14 \mathrm{~ms}$ for high $\mathrm{KCl}$. In (F), synaptic currents in differentiated cells in vitro evoked through external bipolar macroelectrodes; each trace represents an average of ten consecutive signals subtracted from the stimulation artifact; stimulation parameters: 5 stimuli at $400 \mathrm{~ms} 1$ to $10 \mathrm{~V}$ and $1 \mathrm{~ms}$ pulse-duration, 10 sweeps. In Cell 1, synaptic currents with long decay time were induced and blocked completely with $10 \mu \mathrm{M}$ bicuculline methiodide, a selective $\mathrm{GABA}_{A}$-receptor antagonist; in cell 2, residual currents with short decay time persisted after blocking bicuculline, and this component disappeared after $10 \mu \mathrm{M}$ 6-cyano-7-nitroquinoxaline-2,3-dione (CNOX), an AMPA-antagonist. In (G), the percentage of cells with GABAergic and glutamatergic synapses, in $(\mathbf{H})$, the percentage of current-reduction with bicuculline and CNOX, and in (I) the average time constants of the bicuculline- and CNOX-sensitive synaptic components, are depicted.

nifedipine $(p<0.001), 14.3 \pm 1.1 \%$ in $\mathrm{Ni}^{2+}(p<0.001), 9.4 \pm$ $0.9 \%$ in EGTA $(p<0.001)$, and $0.2 \pm 0.1 \%$ in $\mathrm{Cd}^{2+}(p<0.001)$ (see Figure 4B). The average MAP2ab- and synaptophysinfluorescence intensity showed a similar decrease (Figures 4D,F). Therefore, blocking electrical activity or voltage-dependent $\mathrm{Ca}^{2+}$. influx in different ways impaired the acquisition of a mature neuronal phenotype. Most importantly, specifically blocking L-type $\mathrm{Ca}^{2+}$-channels with nifedipine significantly reduced differentiation and synapse formation, highlighting the importance of this type of channel in proper neuronal maturation.

\section{HIGH CAMP LEVELS INCREASED L-TYPE $\mathrm{Ca}^{2+}{ }^{2}$ CURRENTS IN DEVELOPING NEURONS}

In order to study the different subtypes of $\mathrm{Ca}^{2+}$ currents found in developing NPC-derived neurons, we dissected $\mathrm{Ca}^{2+}$ currents with specific pharmacological blockers and performed voltage 

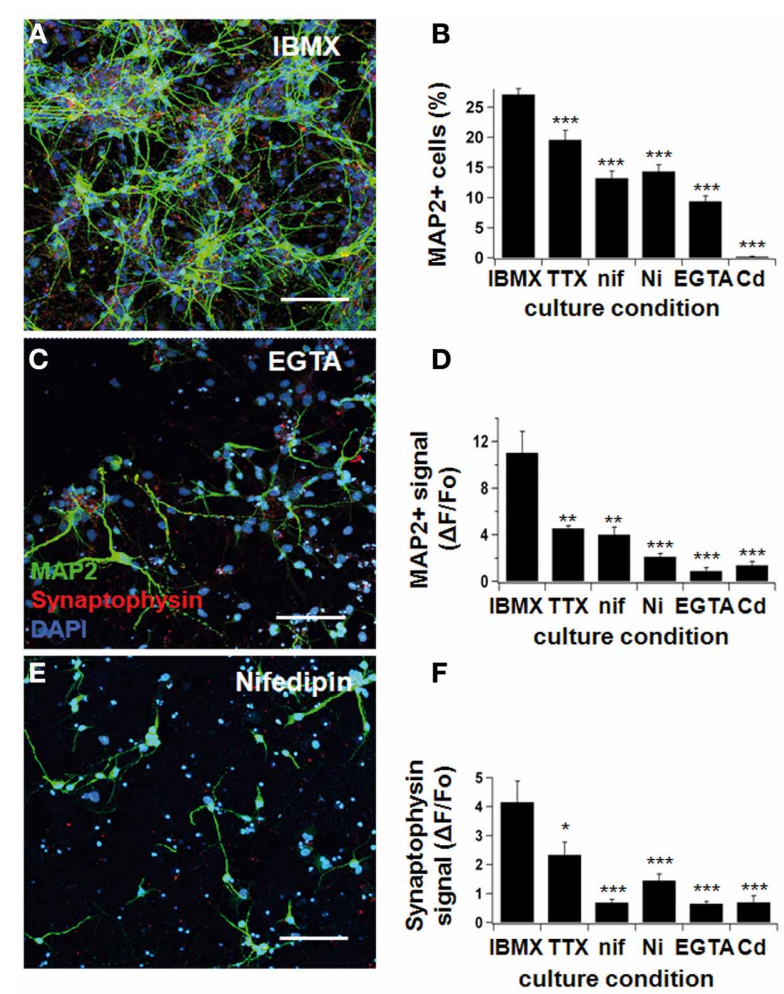

FIGURE 4 | Neurodifferentiation was impaired by $\mathbf{C a}^{2+}$-blockers. NPCs were cultivated in IBMX, as previously described. One hundred nanomolar tetrodotoxin, $10 \mu \mathrm{M}$ nifedipine, $50 \mu \mathrm{M} \mathrm{Ni}^{2+}, 500 \mu \mathrm{M}$ EGTA, and $50 \mu \mathrm{M}$ $\mathrm{Cd}^{2+}$ were added to the culture medium. After 7 days, cultures were fixed and stained for MAP2ab and synaptophysin, and pictures were taken under a confocal microscope (A,C,E). Neuronal differentiation was ascertained three different ways: by counting the number of MAP2-positive cells (B), by determining the fluorescence signal intensity for MAP2 (D), and

synaptophysin (F) by confocal microscopy (see text). The yield of neuronal cells was significantly reduced when $\mathrm{Na}^{+}$- and $\mathrm{Ca}^{2+}$-blockers were added to the culture medium. Green represents AlexaFluor 488 and red, AlexaFluor 568. Scale bars $150 \mu \mathrm{m}$

clamp recordings (Figure 5). On the 7th differentiation day, L-type $\mathrm{Ca}^{2+}$-currents sensitive to nifedipine accounted for $43.7 \pm$ $7.3 \%$ of the total $\mathrm{Ca}^{2+}$ influx at a membrane potential of $10 \mathrm{mV} . \Omega-$ conotoxin GVIA (N-type $\mathrm{Ca}^{2+}$-blocker) blocked $2.9 \pm 3.6 \%$ of the $\mathrm{Ca}^{2+}$-currents; SNX-482 (R-type blocker) blocked $3.8 \pm$ $3.8 \%$; $\omega$-agatoxin IVA (P/Q-type blocker) blocked $5.8 \pm 1.3 \%$; $\mathrm{Ni}^{2+}$ (T-type blocker) blocked $33.3 \pm 4.6 \%$; and $\mathrm{Cd}^{2+}$ blocked $88.4 \pm 1.3 \%$ of the total $\mathrm{Ca}^{2+}$ current (Figure 5F). These results clearly demonstrate the predominance of L-type $\mathrm{Ca}^{2+}$ channels in differentiated NPCs.

As shown above, the number of mature neurons derived from NPCs was significantly higher in culture conditions with increased intracellular cAMP-concentrations (IBMX or Forskolin). We also demonstrated that blocking $\mathrm{Ca}^{2+}$ inhibits neurogenesis in vitro. As L-type $\mathrm{Ca}^{2+}$ channels can be phosphorylated by PKA, we studied the effects of IBMX on wholecell $\mathrm{Ca}^{2+}$ currents in developing neurons. Rectangular voltage pulses evoked large $\mathrm{Ca}^{2+}$ currents 1 week after differentiation in
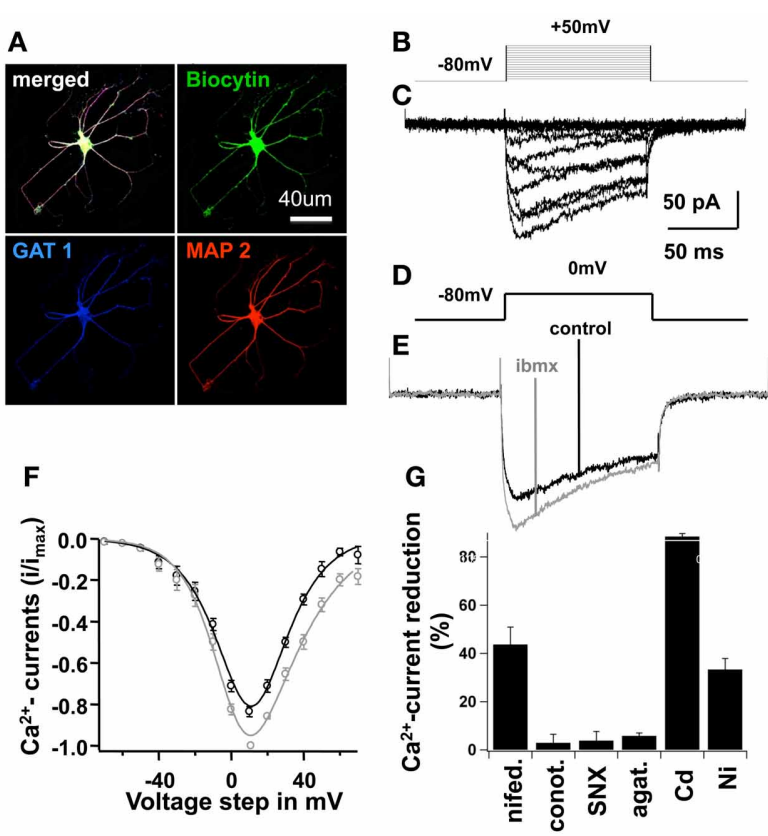

FIGURE 5 | High cAMP increased L-type $\mathrm{Ca}^{2+}$-currents in mature cells. In (A), an example of a mature cell is shown; this cell was filled with Biocytin during recording and further stained for MAP2 (a mature neuronal marker), and Gat-1 (GABA amino-transporter) after fixation. In (B), stimulation protocol in voltage-clamp, pulse duration $100 \mathrm{~ms}$, holding potential $-80 \mathrm{mV}$, stimuli from -70 to $50 \mathrm{mV}$ at $10 \mathrm{mV}$ increments. In (C), voltage-clamp traces, average of 5 consecutive sweeps with subtraction of leak and capacitive currents (see text), showing $\mathrm{Ca}^{2+}$-influx currents. In (D), voltage pulse of $0 \mathrm{mV}$ to obtain traces shown in (E). In (E), $\mathrm{Ca}^{2+}$-influx was recorded in a control situation using the standard bath saline solution, and with $0.5 \mathrm{mM}$ IBMX alone. Traces represent average of 10 consecutive sweeps, for at least $5 \mathrm{~min}$; series resistance remained constant throughout the experiment. In (F), current-voltage (I-V) relationship of $\mathrm{Ca}^{2+}$-influx under each condition mentioned above, bars represent SEM, data were fitted with a modified Goldman-Hodgkin-Katz equation of the form $/(V)=$ $P V([D-\exp (-V / C)] /[1-\exp (V / C)]) *\left[1 /\left(1+\exp \left[\left(V_{1 / 2}-V\right) / V_{\text {slope }}\right]\right)\right]$, see text. In (G), $\mathrm{Ca}^{2+}$-current peaks at $0 \mathrm{mV}$ were recorded with different specific $\mathrm{Ca}^{2+}$-blockers of $\mathrm{L}, \mathrm{T}, \mathrm{P} / \mathrm{Q}$ and $\mathrm{N}$-type $\mathrm{Ca}^{2+}$-channels to dissect the current-subtypes present in NSCs at this maturation phase. Bars represent percentage of current reduction in the control situation and after blocker wash-in.

IBMX and BDNF, with a maximal current amplitude of $10 \mathrm{mV}$ (Figure 5). Recordings performed with and without IBMX in the bath solution showed an increased $\mathrm{Ca}^{2+}$ current amplitude of 182 $\pm 31 \mathrm{pA}$ in the presence of IBMX as compared to control medium $(-152 \pm 27 \mathrm{pA}, p<0.01, n=6)$.

To our knowledge, this is the first demonstration of the acute effect of cAMP on voltage-gated $\mathrm{Ca}^{+2}$ channels in NPC-derived developing neurons.

\section{NIFEDIPINE BLOCKED L-TYPE $\mathrm{Ca}^{2+}$ CURRENTS IN DIFFERENTIATING NEURONS}

The next question was whether the inhibitory effect of nifedipine was due to the blocking of L-type $\mathrm{Ca}^{2+}$ channels during neuronal differentiation. To address this question, $\mathrm{Ca}^{2+}$ currents were recorded during in vitro differentiation, more specifically on the 
1st, 3rd, and 5th days, with and without nifedipine in the differentiation medium. Figure 6 shows typical $\mathrm{Ca}^{2+}$ currents recorded from a cell cultivated under standard conditions (A) and in nifedipine (B). The I-V relationship of 10 pooled cells clearly

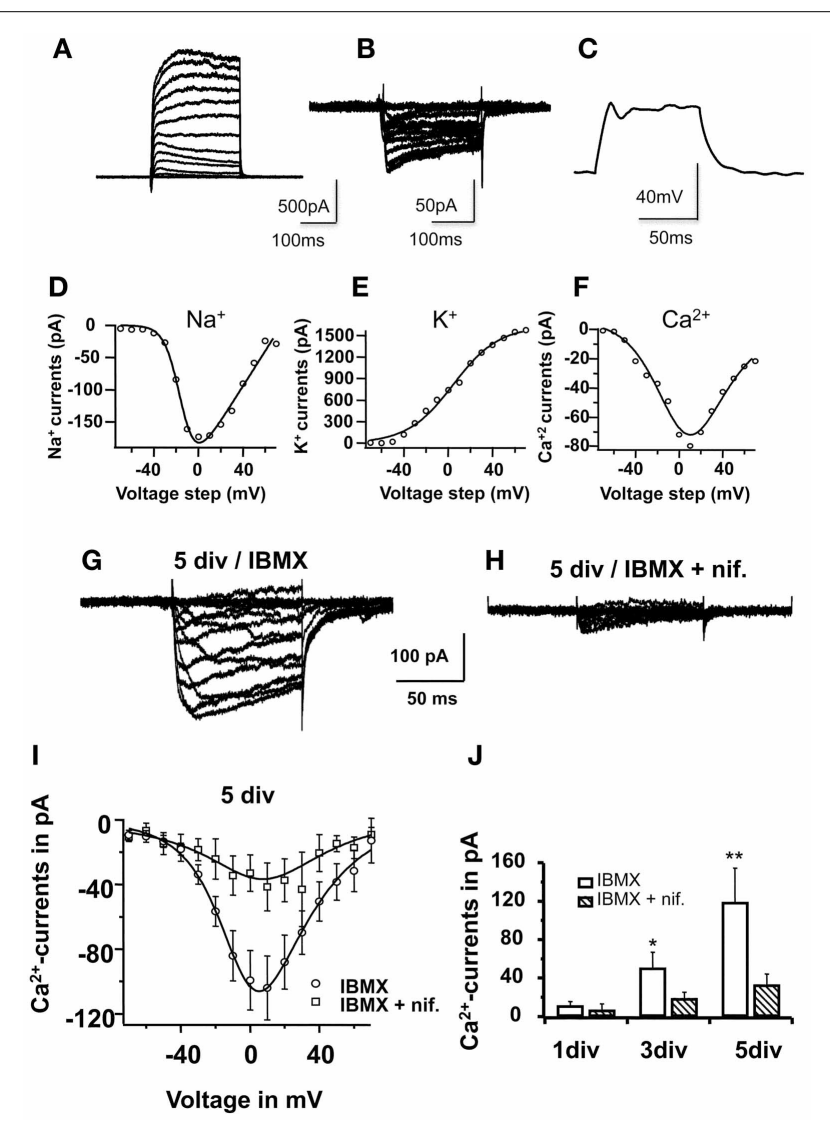

FIGURE 6 | Nifedipine blocked L-type-Ca ${ }^{2+}$-currents in maturing cells. In (A), voltage-clamp traces showing the $1-V$ relationship (5 sweeps) for $\mathrm{Na}^{+}$and $\mathrm{K}^{+}$-currents in a cell on the $2 \mathrm{nd}$ day in vitro. Note the small $\mathrm{Na}^{+}$ component in relation to the relatively large $\mathrm{K}^{+}$component, mainly comprised of slow-rectifying $\mathrm{K}^{+}$-channels. In (B), I-V voltage clamp traces showing $\mathrm{Ca}^{2+}$ - influx currents in another cell also on the 2 nd day in vitro. In (C), current clamp traces after $+40 \mathrm{pA}$ stimulus, recorded form the same cell shown in (A), showing a small voltage oscillation not sufficient to elicit an action potential. In (E), (F), and (G), $\mathrm{Na}^{+}, \mathrm{K}^{+}$, and $\mathrm{Ca}^{2+}$ - activation curves, respectively; $(\mathbf{D}, \mathbf{E})$ were derived from the traces shown in $(\mathbf{A})$, and (F) was derived from the traces shown in (B). All cells were recorded on the 2 nd day in vitro. The mathematical modeling was based on the Boltzmann equation multiplied with a driving force, considering the reversal potential for $\mathrm{K}^{+}$and for $\mathrm{Na}^{+}$, calculated as $-95 \mathrm{mV}$ and $80 \mathrm{mV}$, respectively, while taking the solutions used into consideration (see text). For $\mathrm{Ca}^{2+}$, the $\mathrm{I}-\mathrm{V}$ relationships were fitted with a modified Goldman-Hodgkin-Katz equation (see text). In (G) and (H), voltage-clamp traces obtained for $\mathrm{Ca}^{2+}$ but on the 5 th differentiation day, before complete functional maturation was achieved. In (G), example of a typical recording from a cell cultivated in $0.5 \mathrm{mM}$ IBMX. In (H), example of a typical recording from a parallel culture in IBMX and $10 \mu \mathrm{M}$ nifedipine. Traces represent average of 5 consecutive sweeps. In (I), I-V relationship of $\mathrm{Ca}^{2+}$-currents under both conditions in 10 different cells; data were fitted with a modified Goldman-Hodgkin-Katz equation. In (J), $\mathrm{Ca}^{2+}$-peak currents at $0 \mathrm{mV}$ on $1 \mathrm{st}$, 3rd, and 5 th differentiation days, in cells cultivated with and without nifedipine. Each bar represents recordings from 10 cells. demonstrated that nifedipine chronically blocked $\mathrm{Ca}^{2+}$ influx throughout the differentiation period. An analysis of the progression of peak $\mathrm{Ca}^{2+}$ current at $0 \mathrm{mV}$ during neuronal maturation under standard differentiation conditions revealed an increase in current: $11 \pm 4 \mathrm{pA}$ on the first day, $50 \pm 16 \mathrm{pA}$ on the third day $(p<0.05)$, and $119 \pm 36 \mathrm{pA}$ on the fifth day $(p<0.01)$. By contrast, when cells were constantly cultivated with nifedipine, the peak $\mathrm{Ca}^{2+}$ current did not increase significantly $(7 \pm 6 \mathrm{pA}$ on the first day, $19 \pm 7 \mathrm{pA}$ on the third, $p>0.1$, and $33 \pm 11 \mathrm{pA}$ on the fifth day, $p>0.1$, Figure 6D). These data clearly show that in addition to blocking L-type $\mathrm{Ca}^{2+}$ currents, the acute application of nifedipine also inhibits the developmental up-regulation of this influx.

\section{BLOCKING OF L-TYPE $\mathrm{Ca}^{2+}$ CURRENTS PREVENTS CREB PHOSPHORYLATION IN DIFFERENTIATING NSCS}

In the standard differentiation medium, the relative pCREBfluorescence intensity $\left(\Delta \mathrm{F} / \mathrm{F}_{0}\right)$ increased from $1.6 \pm 0.1$ on the first day to $5.4 \pm 0.3$ on the seventh day $(p<0.01)$. When cultivated under nifedipine, however, pCREB did not significantly increase $(1.5 \pm 0.2$ vs. $1.3 \pm 0.2$ in control, $p>0.1$, Figures 7A-C). Because the total cell number differed slightly under the two sets of conditions, the pCREB-fluorescence was normalized to the DAPI-fluorescence intensity, which is proportional to cell number. Thus, the pCREB signal increased from $0.18 \pm 0.01$ to $1.05 \pm 0.04(p<0.01)$ without nifedipine, and only from $0.14 \pm 0.02$ to $0.19 \pm 0.03(p>0.1)$ with nifedipine (see Figure 7D). Taken together, these results indicate that intracellular $\mathrm{Ca}^{2+}$ levels interfere with CREB phosphorylation, which under normal conditions acts synergistically with cAMP to promote neuronal maturation.

To determine whether nifedipine causes significantly high rates of cell death at the used dose, we performed a cell viability assay, as described above (see methods, Cell Viability Assay). To this end, dead and total cells were quantified at the 1st, 3 rd, and 5th days in vitro. Under IBMX, the yield of dead cells peaked at $2.7 \pm 1.3 \%$ on the 5th day, which was not significantly different from the $4.5 \pm 2.1 \%$ observed in the nifedipine cultures on the 1st day $(p>0.05)$. Based on this, we suggest that the difference in cell densities observed across cultures might have been caused by a reduced cell division rate under reduced $\mathrm{Ca}^{2+}$. Nevertheless, the possibility that nifedipine might be acting preferentially on neural progenitor cells (NPCs) cannot be completely excluded at this point, as this would also explain why reduced calcium led to lower rates of neurogenesis.

\section{DISCUSSION}

Although much knowledge has been gained in recent years regarding stem cell biology and plasticity, the mechanisms that govern complete neuronal functional maturation remain largely unknown (Scheffler et al., 2005; Ge et al., 2006). In the current study, we present several novel findings pertaining to the differentiation and maturation of SVZ-derived neural progenitor cells (NPCs). First, we found that increasing cAMP levels by inhibiting phosphodiesterase activity is sufficient to support the rapid functional maturation of neuronal progenitors into fully 

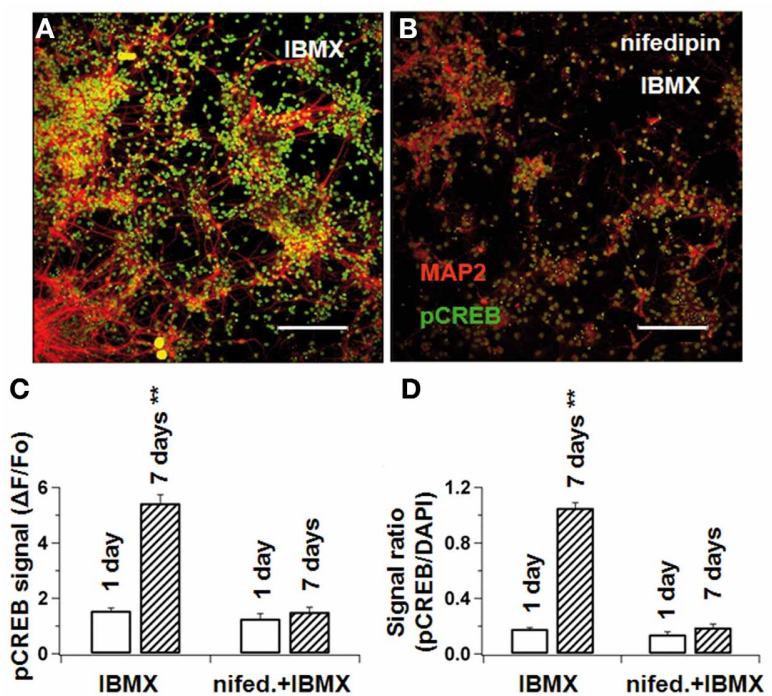

FIGURE 7 | L-type $\mathrm{Ca}^{2+}$-blockade prevents CREB phosphorylation in differentiating NPCs. NPCs were cultivated either under IBMX (A) or IBMX with nifedipine (B). After 1 and 7 days, cultures were fixed and stained concomitantly for MAP2ab and phosphorylated CREB. pCREB-signal intensity was measured by confocal microscopy. In (C), pCREB signal at the beginning and end of differentiation in cultures with IBMX and IBMX+nifedipine. In (D), the pCREB/DAPI-signal ratio was calculated to correct for different cell densities. In both measurements, nifedipine prevented $\mathrm{pCREB}$ phosphorylation during differentiation. Scale bars $150 \mu \mathrm{M}$

functional neurons; this maturation involves the high-density expression of voltage-gated ion channels, the high-frequency firing of APs and the formation of functional glutamatergic and GABAergic synaptic contacts. Second, we showed that this cAMPinduced acceleration in maturation is dependent on the early up-regulation of L-type $\mathrm{Ca}^{2+}$ currents. Finally, early electrical activity and voltage-gated $\mathrm{Ca}^{2+}$ influx are critically important for the activation of transcription factors such as pCREB, which induce neuronal outgrowth and synapse formation.

According to (Lipscombe et al., 2004), $\mathrm{Ca}_{\mathrm{v}} 1$ channels, which are expressed in skeletal, cardiac and smooth muscle cells, as well as in neurons and endocrine cells, can mediate numerous cell functions. $\mathrm{Ca}^{2+}$ is believed to be involved in controlling cell survival and death (Moulder et al., 2003), as well as in neuronal differentiation (Deisseroth et al., 2003; Lohmann, 2009). Furthermore, intracellular $\mathrm{Ca}^{2+}$ signals correlate with the regulation of neuronal gene expression (Toescu and Verkhratsky, 2004), and can activate numerous transcription factors, such as CREB, C/EBT $\beta$, MEF-2, NT-ATc4, NFkB, and c-fos (Weick et al., 2003). In cortical neurons, $\mathrm{Ca}_{v} 1$-mediated $\mathrm{Ca}^{2+}$ influx stimulates the expression of various genes that regulate neuronal survival and plasticity through CREB phosphorylation (Dolmetsch et al., 2001). Interestingly, when we cultured NPCs without cAMP, MAP2-positive neurons were still generated $(6.4 \pm 1.2 \%$ in basal medium, Figure 1D). However, blocking all $\mathrm{Ca}^{2+}$ currents with $\mathrm{Cd}^{2+}$ abolished differentiation completely. Our finding confirms that $\mathrm{Ca}^{2+}$ signaling is critical for proper neuronal differentiation.
In a study of rat dentate gyrus, Stocca et al. (2008) found that young granule cells express a relatively high density of T-type $\mathrm{Ca}^{2+}$ channels that facilitate the generation of low-threshold $\mathrm{Ca}^{2+}$-spikes and boost suprathreshold action potentials with very small excitatory currents. In the current study, we demonstrated the role of L-type calcium channels in neural stem cell differentiation. When we selectively blocked this type of channel with nifedipine, we observed a decrease in the number of mature neurons in culture, whereas applying the L-channel activator Bay $\mathrm{K}$ 8644 produced the opposite effect (see also D'Aascenzo et al., 2006). Furthermore, these channels are expressed early in the maturation process. Our data revealed that small $\mathrm{Ca}^{2+}$ currents were measurable in the differentiation medium after only 1 day; furthermore, blocking them as early as the first day impeded neuronal phenotype acquisition.

Previous work has also highlighted the importance of excitatory stimuli for complete functional differentiation and synaptic maturation (Ge et al., 2006). Newborn granule cells in the dentate gyrus of the adult hippocampus first receive GABAergic synapses before they are innervated by glutamatergic synaptic inputs. GABA initially exerts an excitatory action on newborn neurons thanks to the relatively high chloride ion concentration in the cytoplasm. This GABAergic excitation leads to $\mathrm{Ca}^{2+}$ influx, which in turn facilitates neuronal differentiation and dendritic outgrowth in young neurons (Ge et al., 2006). Deisseroth et al. (2004) induced depolarization with glutamate or high $\mathrm{K}^{+}$, which resulted in increased neuronal cell production. This effect was then partially reversed when they added nifedipine to the medium, suggesting that the activation of $\mathrm{Ca}_{\mathrm{v}} 1.2 / 1.3$ (L-type) $\mathrm{Ca}^{2+}$ channels plays a role in neurogenesis. Our own data revealed that blocking L-type $\mathrm{Ca}^{2+}$ channels with nifedipine had a slightly stronger effect than TTX on the suppression of neuronal differentiation (Figure 4). Taken together, these data confirm the critical role of early electrical excitability and membrane depolarization mediated by $\mathrm{Na}^{+}$channels, $\mathrm{Ca}^{2+}$ channels or both. Furthermore, in this study we also showed that these processes may be observed as early as the first few days of neuronal development.

A vast body of work has shown the great neurogenic potential of fetal-derived NSCs and neuronal progenitor cells (Isacson, 2009). In a previous study from our group we demonstrated the superior neurogenic potential of fetal-derived NSC as compared to adult mesenchymal stem cells (Lepski et al., 2010). The role of specific neurotrophic factors and signaling molecules such as BDNF (Leng et al., 2009), NT3 (Yoo et al., 2007), or Wnt (Jagasia et al., 2009) in the functional maturation of neural stem cells has also been reported by several authors. Similarly, many intracellular signaling molecules such as cAMP, $\mathrm{Ca}^{2+}$, or GSK3 have been shown to be important for neurogenesis and early neuronal development (Nakagawa et al., 2002; Lohmann, 2009; Hur and Zhou, 2010). Nakagawa et al. (2002) reported that inhibition of phosphodiesterase4 (PDE4) by rolipram strongly increases cognitive functions and the number of newly generated neurons in the hippocampus. In the current study, we showed that inhibition of PDE by IBMX significantly increases the number of MAP2positive neurons, as well as the expression of voltage-gated $\mathrm{Na}^{+}$ and $\mathrm{K}^{+}$channels (and consequently, the firing frequency); these effects are observed within 1 week of treatment. Furthermore, 
the number of glutamatergic and GABAergic currents was also significantly increased, which may be partially due to the PKAmediated phosphorylation of synapsins (Kao et al., 2002). Taken together, these results support the notion that cAMP-signaling is critically important for neuronal development (Li et al., 2011). Additionally, the increase in L-type currents is most probably mediated by PKA-mediated phosphorylation (Dai et al., 2009). Our data further indicate that BDNF alone is not sufficient and may act jointly with increased cAMP signaling to effectively support neuronal maturation. In sum, IBMX, cAMP and BDNF appear to constitute the minimal in vitro requirements for proper differentiation and maturation of NPCs.

How do cAMP and $\mathrm{Ca}^{2+}$-signaling interact to support neuronal differentiation and maturation? It has been reported that embryonic spinal cord neurons generate spontaneous $\mathrm{Ca}^{2+}$ and cAMP oscillations (Gorbunova and Spitzer, 2002). Furthermore, blocking $\mathrm{Ca}^{2+}$ transients decreases the frequency of cAMP transients and vice versa. In cortical NPCs, we found that increasing cAMP concentration by blocking PDE up-regulated voltage-gated $\mathrm{Ca}^{2+}$ currents during the first few days of differentiation. Conversely, blocking voltage-gated $\mathrm{Ca}^{2+}$ influx inhibited cAMP-induced neuronal differentiation. Therefore, both cAMP and $\mathrm{Ca}^{2+}$ seem to be crucial components that together play a pivotal role in neuronal differentiation and maturation. Our data strongly support a positive feedback model involving sequential increases in cAMP signals and voltagedependent $\mathrm{Ca}^{2+}$ transients during early neuronal differentiation (Willoughby and Cooper, 2007). The $\mathrm{Ca}^{2+}$ transients, in turn, lead to CREB activation. As discussed above, the transcription of many proteins important for neuronal growth and synapse formation is regulated during this important stage in neuronal development (Jagasia et al., 2009; Merz et al., 2011).

\section{REFERENCES}

Auerbach, J. M., Eiden, M. V., and McKay, R. D. (2000). Transplanted CNS stem cells form functional synapses in vivo. Eur. J. Neurosci. 12, 1696-1704. doi: 10.1046/j.14609568.2000.00067.x

D'Aascenzo, M., Piacentini, R., Casalbore, P., Budoni, M., Pallini, R., Azzena, G. B., et al. (2006). Role of L-type $\mathrm{Ca} 2+$ channels in neural stem/progenitor cell differentiation. Eur. J. Neurosci. 23, 935-944. doi: 10.1111/j.1460-9568.2006.04628.x

Dai, S., Hall, D. D., and Hell, J. W. (2009). Supramolecular assemblies and localized regulation of voltagegated ion channels. Physiol. Rev. 89, 411-452. doi: 10.1152/physrev.00029.2007

Deisseroth, K., Mermelstein, P. G., Xia, H., and Tsien, R. W. (2003). Signaling from synapse to nucleus: the logic behind the mechanisms. Curr. Opin. Neurobiol. 13, 354-365. doi: $\quad 10.1016 / \mathrm{S} 0959-4388(03)$ 00076-X
Deisseroth, K., Singla, S., Toda, H., Monje, M., Palmer, T. D., and Malenka, R. C. (2004). Excitationneurogenesis coupling in adult neural stem/progenitor cells. Neuron 42, 535-552. doi: 10.1016/S08966273(04)00266-1

Dolmetsch, R. E., Pajvani, U., Fife, K., Spotts, J. M., and Greenberg, M. E. (2001). Signaling to the nucleus by an L-type calcium through the MAP kinase pathway. Science 294, 333-339. doi: 10.1126/science. 1063395

Dworkin, S., and Mantamadiotis, T. (2010). Targeting CREB signalling in neurogenesis. Expert Opin. Ther. Targets 14, 869-879. doi: 10.1517/14728222.2010.501332

Fujioka, T., Fujioka, A., and Duman, R. S. (2004). Activation of cAMP signaling facilitates the morphological maturation of newborn neurons in adult hippocampus. J. Neurosci. 24, 319-328. doi: 10.1523/JNEUROSCI.1065.03.2004 channel-calmodulin complex

In conclusion, here we showed that increasing cAMP in the culture system facilitates the generation of mature neurons, while decreasing $\mathrm{Ca}^{2+}$ influx consistently reduces neuronal production. First, we demonstrated that $\mathrm{Ca}^{2+}$ currents in neural stem cells from the fetal subventricular zone are mainly mediated by L-type $\mathrm{Ca}^{2+}$ channels. Nifedipine did not only block $\mathrm{Ca}^{2+}$-influx through L-type channels, but it also effectively inhibited neuronal differentiation. This confirms that voltage-gated $\mathrm{Ca}^{2+}$ signaling is critically important for developing NPCs. It seems that $\mathrm{Ca}^{2+}$ transients that are elicited during normal cell firing may play a pivotal role in proper neuronal maturation. In neurogenic areas, this appears to be driven by excitatory GABAergic inputs to maturating cells, as has been demonstrated in vivo (Tozuka et al., 2005; Ge et al., 2006; Jagasia et al., 2009). Second, we showed that an acute increase in intracellular cAMP leads to an increase in $\mathrm{Ca}^{2+}$ influx through L-type channels. Finally, L-type $\mathrm{Ca}^{2+}$-blockade impaired CREB phosphorylation, a major signaling hub for neuronal development. Therefore, the data reported herein support a model in which cAMP- and $\mathrm{Ca}^{2+}$-dependent pathways positively interact to promote the differentiation of neuronal progenitor cells into fully functional neurons.

To our knowledge, this is the first demonstration of an acute and chronic interaction between $\mathrm{Ca}^{2+}$ - and cAMP-dependent pathways during in vitro neurogenesis. Therefore, these findings represent an important contribution to our understanding of the mechanisms underlying neuronal maturation and to the future development of new restorative strategies based on cell therapy.

\section{ACKNOWLEDGMENTS}

The present work was sponsored by DFG (Deutsche Forschungsgemeinschaft), DAAD (Deutscher Akademischer Austauschdienst), the German Parkinson Foundation and BMBF (Bundesministerium für Bildung und Forschung, Germany).

Ge, S., Goh, E. L., Sailor, K. A., Kitabatake, Y., Ming, G. L., and Song, H. (2006). GABA regulates synaptic integration of newly generated neurons in the adult brain 6. Nature 439, 589-593. doi: 10.1038 /nature 04404

Giachino, C., De, M. S., Giampietro C., Parlato, R., Perroteau, I., Schutz, G., et al. (2005). cAMP response element-binding protein regulates differentiation and survival of newborn neurons in the olfactory bulb. J. Neurosci. 25, 10105-10118. doi: 10.1523/JNEUROSCI.351205.2005

Gorbunova, Y. V., and Spitzer, N. C. (2002). Dynamic interactions of cyclic AMP transients and spontaneous $\mathrm{Ca}(2+)$ spikes. Nature 418, 93-96. doi: 10.1038/ nature 00835

Herold, S., Jagasia, R., Merz, K. Wassmer, K., and Lie, D. C. (2011). CREB signalling regulates early survival, neuronal gene expression and morphological development in adult subventricular zone neurogenesis. Mol. Cell. Neurosci. 46, 79-88. doi: 10.1016/j.mcn.2010.08.008

Hur, E. M., and Zhou, F. Q. (2010). GSK3 signalling in neural development. Nat. Rev. Neurosci. 11, 539-551. doi: 10.1038/nrn2870

Isacson, O. (2009). Cell therapy ahead for Parkinson's disease. Science 326, 1060. doi: 10.1126/science.326.5956.1060-b

Jagasia, R., Steib, K., Englberger, E., Herold, S., Faus-Kessler, T., Saxe, M., et al. (2009). GABA-cAMP response element-binding protein signaling regulates maturation and survival of newly generated neurons in the adult hippocampus. J. Neurosci. 29, 7966-7977. doi: 10.1523/JNEUROSCI.1054-09.2009 Kao, H. T., Song, H. J., Porton, B., Ming, G. L., Hoh, J., Abraham, M., et al. (2002). A protein kinase A-dependent molecular switch in synapsins regulates neurite outgrowth. Nat. Neurosci. 5, 431-437. doi: $10.1038 / \mathrm{nn} 840$ 
Leng, J., Jiang, L., Chen, H., and Zhang, X. (2009). Brain-derived neurotrophic factor and electrophysiological properties of voltage-gated ion channels during neuronal stem cell development. Brain Res. 1272, 14-24. doi: 10.1016/j.brainres.2009.03.048

Lepski, G., Jannes, C. E., Maciaczyk, J., Papazoglou, A., Mehlhorn, A. T., Kaiser, S., et al. (2010). Limited $\mathrm{Ca} 2+$ and PKA-pathway dependent neurogenic differentiation of human adult mesenchymal stem cells as compared to fetal neuronal stem cells. Exp. Cell Res. 316, 216-231. doi: 10.1016/j.yexcr.2009.08.006

Lepski, G., Jannes, C. E., Wessolleck, J., Kobayashi, E., and Nikkhah, G. (2011a). Equivalent neurogenic potential of wild-type and GFP-labeled fetal-derived neural progenitor cells before and after transplantation into the rodent hippocampus. Transplantation 91, 390-397. doi: 10.1097/TP.0b013e3182063083

Lepski, G., Maciaczyk, J., Jannes, C. E., Maciaczyk, D., Bischofberger, J., and Nikkhah, G. (2011b). Delayed functional maturation of human neuronal progenitor cells in vitro. Mol. Cell. Neurosci. 47, 36-44. doi: 10.1016/j.mcn.2011.02.011

Li, Y. F., Cheng, Y. F., Huang, Y., Conti, M., Wilson, S. P., O'Donnell, J. M., et al. (2011). Phosphodiesterase-4D knock-out and RNA interference-mediated knock-down enhance memory and increase hippocampal neurogenesis via increased cAMP signaling.
J. Neurosci. 31, 172-183. doi: 10.1523/JNEUROSCI.5236-10.2011

Lipscombe, D., Helton, T. D., and $\mathrm{Xu}, \quad W . \quad$ (2004). L-type calcium channels: the low down. J. Neurophysiol. 92, 2633-2641. doi: 10.1152/jn.00486.2004

Lohmann, C. (2009). Calcium signaling and the development of specific neuronal connections. Prog. Brain Res. 175, 443-452. doi: 10.1016/S0079-6123(09)17529-5

Merz, K., Herold, S., and Lie, D. C. (2011). CREB in adult neurogenesis - master and partner in the development of adult-born neurons? Eur. J. Neurosci. 33, 1078-1086. doi: 10.1111/j.1460-9568.2011.07606.x

Moulder, K. L., Cormier, R. J., Shute, A. A., Zorumski, C. F., and Mennerick, S. (2003). Homeostatic effects of depolarization on $\mathrm{Ca} 2+$ influx, synaptic signaling, and survival. J. Neurosci. 23, 1825-1831.

Nakagawa, S., Kim, J. E., Lee, R., Malberg, J. E., Chen, J., Steffen, C., et al. (2002). Regulation of neurogenesis in adult mouse hippocampus by cAMP and the cAMP response element-binding protein. J. Neurosci. 22, 3673-3682.

Redmond, L., Kashani, A. H., and Ghosh, A. (2002). Calcium regulation of dendritic growth via CaM kinase IV and CREBmediated transcription. Neuron 34, 999-1010. doi: 10.1016/S0896-6273 (02)00737-7

Scheffler, B., Walton, N. M., Lin, D. D., Goetz, A. K., Enikolopov, G., Roper, S. N., et al. (2005). Phenotypic and functional characterization of adult brain neuropoiesis. Proc. Natl. Acad.
Sci. U.S.A. 102, 9353-9358. doi: 10.1073/pnas.0503965102

Song, H. J., Stevens, C. F., and Gage, F. H. (2002). Neural stem cells from adult hippocampus develop essential properties of functional CNS neurons. Nat. Neurosci. 5, 438-445. doi: $10.1038 / \mathrm{nn} 844$

Stocca, G., Schmidt-Hieber, C., and Bischofberger, J. (2008). Differential dendritic $\mathrm{Ca} 2+$ signalling in young and mature hippocampal granule cells. J. Physiol. 586, 3795-3811. doi: 10.1113/jphysiol. 2008.155739

Toescu, E. C., and Verkhratsky, A (2004). Ca2+ and mitochondria as substrates for deficits in synaptic plasticity in normal brain ageing. J. Cell. Mol. Med. 8, 181-190. doi: 10.1111/j.15824934.2004.tb00273.x

Tozuka, Y., Fukuda, S., Namba, T., Seki, T., and Hisatsune, T. (2005). GABAergic excitation promotes neuronal differentiation in adult hippocampal progenitor cells. Neuron 47, 803-815. doi: 10.1016/j.neuron.2005.08.023

Weick, J. P., Groth, R. D., Isaksen, A. L., and Mermelstein, P. G. (2003). Interactions with PDZ proteins are required for L-type calcium channels to activate cAMP response element-binding protein-dependent gene expression. J. Neurosci. 23, 3446-3456.

Willoughby, D., and Cooper, D. M. (2007). Organization and $\mathrm{Ca} 2+$ regulation of adenylyl cyclases in cAMP microdomains. Physiol. Rev. 87, 965-1010. doi: 10.1152/physrev.00049.2006
Yoo, M., Joung, I., Han, A. M., Yoon, H. H., and Kwon, Y. K. (2007). Distinct effect of neurotrophins delivered simultaneously by an adenoviral vector on neurite outgrowth of neural precursor cells from different regions of the brain. J. Microbiol. Biotechnol. 17, 2033-2041.

Conflict of Interest Statement: The authors declare that the research was conducted in the absence of any commercial or financial relationships that could be construed as a potential conflict of interest.

Received: 16 June 2013; accepted: 28 August 2013; published online: 19 September 2013.

Citation: Lepski G, Jannes CE, Nikkhah $G$ and Bischofberger J (2013) cAMP promotes the differentiation of neural progenitor cells in vitro via modulation of voltage-gated calcium channels. Front. Cell. Neurosci. 7:155. doi: 10.3389/fncel. 2013.00155

This article was submitted to the journal Frontiers in Cellular Neuroscience.

Copyright (C) 2013 Lepski, Jannes, Nikkhah and Bischofberger. This is an open-access article distributed under the terms of the Creative Commons Attribution License (CC BY). The use, distribution or reproduction in other forums is permitted, provided the original author(s) or licensor are credited and that the original publication in this journal is cited, in accordance with accepted academic practice. No use, distribution or reproduction is permitted which does not comply with these terms. 


\section{APPENDIX}

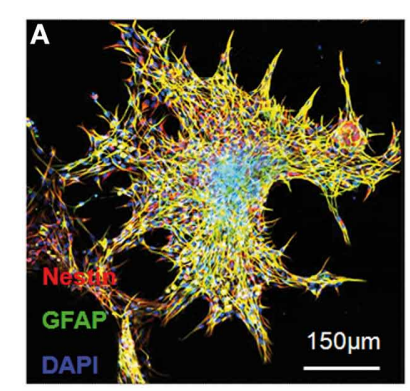

C

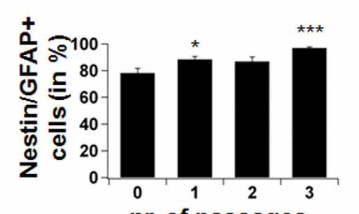

nr. of passages

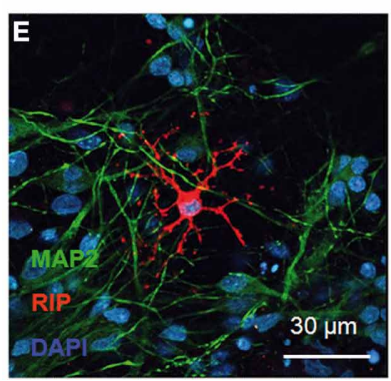

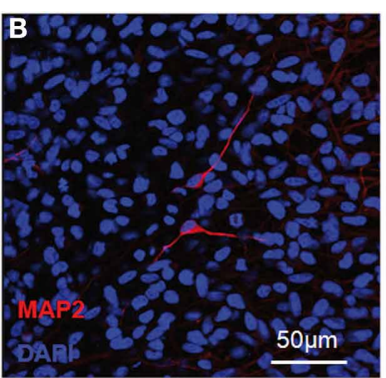

D

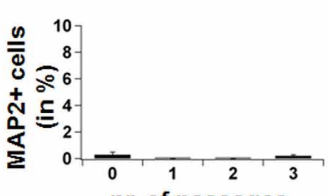

$\mathrm{nr}$. of passages

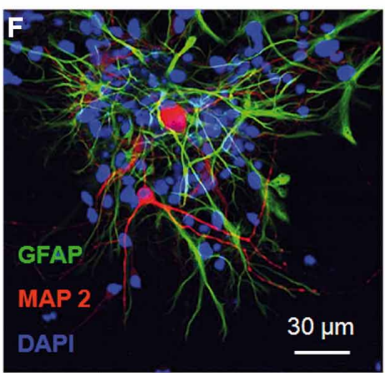

FIGURE A1 | Neural stem cells isolated before differentiation. Cells were expanded in vitro until the formation of free-floating neurospheres. These were plated onto poly-Llysine, and $2 \mathrm{~h}$ after plating, were fixed and immunostained for nestin, GFAP and MAP2 after 0, 1, 2, 3, and more passages. In (A), confocal picture showing nestin and GFAP co-expression in a culture expanded for 3 passages. Note that cells adhere to the culture flask and migrate away from the core of the spheres. In (B),

MAP2ab-staining in the same culture showing that the occurrence of MAP2-positive neurons before differentiation is extremely rare. In (C), the yield of progenitor cells, double-stained for nestin and GFAP, rose gradually with time in expansion culture, as mature cell types died. In (D), no significant MAP2-positivity was seen in the system before differentiation. In (E), confocal microscopy after differentiation in medium rich in CAMP, showing oligodendrocytes (anti-RIP, revealed in red) and neurons (anti-MAP2, revealed in green). In (F), astrocytes (anti-GFAP, green) and neurons (anti-MAP2ab, red). Red represents AlexaFluor568 and green represents AlexaFluor488. 